\title{
The Critique of Leo Strauss to Modernist Political Thought
}

\author{
Mohammad Abedi Ardakani ${ }^{1}$, Mohammad Ali Tavana ${ }^{1} \&$ Gholamreza Mohebzadeh Nobandegani ${ }^{1}$ \\ ${ }^{1}$ Department of Political Sciences, Yazd University, Iran \\ Correspondence: Mohammad Ali Tavana, Department of Political Sciences, Yazd University, Iran. E-mail: \\ Tavana.mohammad@yahoo.com
}

Received: April 29, 2016 Accepted: May 14, 2016 Online Published: August 30, 2016

doi:10.5539/jpl.v9n7p119 URL: http://dx.doi.org/10.5539/jpl.v9n7p119

\begin{abstract}
As a conservative philosopher, Leo Strauss reconsiders and criticizes modern political thought methodologically and epistemologically, in that he believes it has faced crises leading history of philosophical thinking to deviate. To put simply, Strauss claims that the major part of critical thinking arisen in the West is the by-product of the modern political thought. According to this, the present paper reviews Strauss's critique of modern political thought, putting the question "what kind of insights and enlightenments does Strauss' critique of modern political thought encompass?" As a finding of the research, we can hold that Strauss attempted to show that methodology of historical and epistemology of relativism governing modern political thought disregard trans-spatial and timeless principles of natural law; as a result, it substitutes suspicion for real knowledge and certainty.Thus, it encourages nihilism; on the one hand, it introduces any form of autonomous agreement by human beings as fair right, as it neglects universal morality on the other hand, turning it to the matter of validity. Therefore, it resorts to irresponsibility, and eventually introduces human reason as the only instrumental benchmark for living rules, which in turn encompasses the emergence of totalitarianism. The method of the research is an analytical-descriptive method.
\end{abstract}

Keywords: Leo Strauss, classic natural rights, modern political thought, critique

\section{Introduction}

As an American theorist and political philosopher and one of the supporters of classic political philosophy in twentieth century, Leo Strauss (1899-1973) has tried to find the essence and nature of political thought in philosophers similar to classic philosophers throughout his scientific life and to perceive how the political and social problem has created and where is the point of dispute and conflict. Strauss has taken unique and of course complex method in interpretation of works and paradigms of great authors as well as criticism of modernity. He typically followed Platonic attitude and believed that 'city' or the place for political life might be similar to a prison (Namazi, 2013-a, 8-10). Strauss mainly concerned with hermeneutic and interpretation of paradigms presented by great thinkers from Plato and Aristotle to Machiavelli, Hobs, Rousseau, Hegel, and Nietzsche (Bashiriyeh, 2007: 252).

The pivotal point is in paradigm of Strauss that the philosophical facts are not subject to time. Namely, the fundamental questions are common all the times. From this perspective, Strauss disagrees with historicism. According to idea of Strauss, what acts as barrier against proper perception of the classic people is not historic period, but it is dominance of modernist approach that analyzes improperly and dodges to analyze them by virtue of dogmatic and fanatic impression from modern concepts (e.g. advancement and democracy) and or accepts the current historicism paradigm based on which it is impossible to achieve real comments from classic scholars due to hermeneutic and historical reasons (Namazi, 2013-b: 269).

In fact, he intends to analyze natural rights and classic philosophy caused by his special perception of current modernity in the west. He assumes this crisis was deep-rooted in disbelief of western countries in their goals and values. Such disbelief is consequence of theoretical challenges in political philosophy in relation to modernity plans such as value of globalism, link among welfare with justice and salvation and employing knowledge toward human's power (Tarcov \& Pangle, 1994: 61062). The same attitude is starting point to one of the most equivocal approaches that have been so far proposed by him that is that his invitation to return to classic scholars as well as severe critiques to intellectual bases of philosophers in modern period at age of enlightenment such as Machiavelli, Hobs, Rousseau, Nietzsche, and Marx. He tries to show that the modern philosophers could 
overcome to them only by overlooking of reasoning from classic philosophers (Namazi, 2013 - a: 10). Therefore, he has criticized this doctrine dispersedly in addition to being committed to bases of classic natural rights by interpretation of the structure of modern political thought. Rather than criticizing paradigms of pioneers of modernity wave- that typically posited his own thoughts over the time caused weakening and failure for tradition- he asserts that three modernity waves emerged in history of political thought in Europe and broken the wrecked ship of tradition (Tabatabaei, 2011: chapter I).

\section{Natural Rights from Strauss' Attitude}

According Strauss' belief despite of the fact that today the western world no longer believes in natural right in twentieth century or at least likes to pretend it that there is no position for natural rights so to the extent natural rights was considered as necessary in past centuries and or even millennia they seem to be absolute today as well. Rejection of natural right is similar to this point that we accept any right is deemed as a stipulated and institutional matter. Therefore under such circumstances a proper or fair and unfair, independent and superior criterion will be available to us of this conventional right based on which we can arbitrate about the conventional rights (Strauss, 1994: 18). As a result, Strauss express it explicitly that:

'If there is no superior criterion to what a community assumes it as a ideal for that society then we will could never act duly versus our social ideal that deserves to critical arbitration and become distant from it properly. But this point that we concern with value of ideal in our society and can challenge it may indicate that there is something in human that does not perfectly follows the society and therefore we are able and at the same time have to look for a criterion in light of which we can judge about value of ideal in our community as well as ideal of another society.' (Strauss, 1994: 19-20)

Thus, Strauss argues that there is a principle among us called 'Natural Rights'. Namely, all natural organisms have natural closing and possess natural destination and fate that may determine good and evil actions for them (Strauss, 1994: 25-26).

\section{Components of Natural Rights according to Strauss' Attitude}

Natural rights have been discussed among thinkers in various forms since twenty five centuries ago. The major dispute among followers of natural rights and positivists is in that the latter group does not consider the rights as smoothing except a legal system dependent on a certain community while the first group supposes the rights as similar to common ideals in human communities. Of course, human's impression may differ regarding ethical values in different times and places. The adherents of natural rights do not deny the identical nature of this fact but they imply that ideal of rights that is establishment of order tending to goodness will be valid and in force despite of such transformations all the times and places (Movahed, 2005: 245). The theory of natural rights originates from stoic philosophy and ancient Greece where it formed in new shape by topics proposed by Grotius $^{1}$ in the world after ancient Greece and afterwards a chain of most brilliant philosophical figures continued these topics including Spinoza, Locke, Rousseau, Hume, and Kant (Movahed, 2005: 24).

Hobs and Locke processed natural rights based on their perception and interpretation. Jeremy Bentham (18321874) invaded famously to concept and image of natural rights and called it absurd and miserable nonsense'(Freidan, 2005: 18 \& 21) and he maintained that this concept will be deemed as a weapon available to dogmatic parties against the government (Ghorbannia, 2004: 56). Also Thomas Hill Green (1836-1882) considered it entirely as unreasonable (Freidan, 2005: 27). At present age, natural rights is proposed as one of the most equivocal and foremost topics in the contemporary political and social philosophy. In his book 'Natural rights and history', Strauss has examined importance of this matter and showed the reasons which lead to disproving natural rights are not valid. To give answer to this question that if there is any criterion to distinguish among true and false in ethics and politics or not, he gave positive answer and presents some issues in this regard (Rezvani, 2006: 68). In addition to refer to natural rights in this book, he extremely praises Greek attitude about piety and virtue and assesses skeptically neoclassic theory of law (Freidan, 2005: 35).

Of course, according to Strauss' attitude, it is not generally the existing nature in ancient Greece but he considered the same concept of nature that some philosophers such as Plato and Aristotle kept in mind. However in ancient Greece concept of nature was not total clear and certain meaning based on attitude of some persons such as Antiphon (one of well-known sophisticated persons). Term of 'based on nature' apparently means what is in favor of the given person and then this individual's benefit is interpreted according to general criteria of conventional rationality as well (Kleskov, 2013: 59).

\footnotetext{
${ }^{1}$ - Hugo Grotius is a philosopher and lawyer and scientist in political sciences. He was born in Delft at Netherlands in 1583. His famous book is called rights of war and peace.
} 
But based on its classic meaning and what is perceived from this term, the natural rights have been relatively changed and transformed this day, word 'حق' is called Right and the science of rights is called Law and for this reason it is inevitable extremely to confuse these two concepts since Arabic term 'حق 'حقوق 'حق 'حق ' (right) and one examples of lexical common origin which is used as concept of laws and meaning of rights but the single form of this word (حق) may not create confusion in mind. Therefore, if it is discussed about natural rights in various subjects it is intended sometimes the natural laws and natural order among objects and the other time it refers to law of reasoning and rational order in humans' conduct and often the natural rights represent values and freedoms that are concomitant to human's nature and human can enjoy them because of being human (Movahed, 2005: 71).

But one can find generally the three following specifications almost in all of various interpretations from natural rights suggested so far: 1) Universality; 2) Post-socialism; and 3) Consistency and absoluteness.

1) Universality of these rights denotes that their principles are the same in all times and places (Movahed, 2005: 248). Therefore, universality means that these rights are attributed to humans as their natural instruments and equipment. Thus no one could disprove reliability of those rights. Hence no regional, cultural, natural or historic change and diversion may be tolerated against them (Freidan, 2005:37).

2) Natural rights are post-socialist. These rights are not built by any social measure, historic development, and or political initiative and measure. Perfectly vice versa, political communities may be exactly created to ensure from recognition and imposition of natural rights (Freidan; 2005: 37). At first place, natural rights are classic and basically an objective. A binding law and criterion from the past and there are also at present and independent and beyond of human's will (Strauss, 1995: 7-8).

3) Consistency and absoluteness of natural rights results from its independence from any other human (Movahed, 2005: 248). These rights are prior to all considerations that may cause disproving its reliability and enforceability, and or field. Namely, these rights are non-negotiable; they could not be reduced and not be subject to compromise and threat and or deducted (Freidan, 2005: 37). Accordingly, Straus believes that: [natural rights] are a binding and indisputable instruction (Strauss, 1995: 8). It orders us about the activities we should do and bars us from evils. This law does not belong to earthly institutions and no one is allowed to breach them (Parsapoor, 2010: 142). For this reason, followers of natural rights school argue that the natural right may be achieved due to human rationality and all of them acknowledge it. In other words, natural right may exist if it is based on consistent and unchangeable principles (Strauss, 1995: 27).

One can infer from this point here that the main difference among Strauss (as rigid follower of natural rights) with positivists over basis of rights and the required cornerstone for legal rules. The adherents of natural rights assume the rights as common ideal in human communities and consider equity and obedience to natural principles and guidelines as source of their requirement while positivists and followers of historic approach do not assume the rights as anything except a dependent legal system on a certain community and based on agreement (Ghorbannia, 2004: 37). Also, in coordination with supporters of natural rights, Strauss implies: ‘... Consent of mankind is not deemed as requisite condition for presence of natural right and above all, it was known all the times that various concepts of justice may be governed in different periods and places. Thus if we claim that discovery of various similar perceptions at present and by finding this point that the method of attitude toward justice is not the same in all times and places this may impact on definition of essence of problem and or basically disprove that problem that is a useless claim. It seems in fact that political philosophy was born from such confidence in which variation of legal concepts as reasons for absence of natural right or causes of arbitrary basis for any type of rights. We call this paradigm as conventionalism.' (Strauss, 1995: 28)

According to Strauss' attitude, it was assumed in conventionalism that the difference among nature and convention was the paramount one of all distinctions. There was this implicit belief in this paradigm that the nature had extremely high position that was superior to position of any type of social convention or order and nature is the same norm [as general concept of this term]. The paradigm that expressed the right and justice were conventional activities denoted this point that the basis for right and justice in nature while these cases are against nature in final analysis and there is another philosophy of existent rather than these cases based on which the self-proclaimed agreement in human communities may be explicit or implicit. Thus, joint agreement is the basis for right and justice. Of course, the joint agreement may be adequate for administration of peace but it could not justify emerging of fact. The historic school had not disclosed this point that specific or historic criteria achieve ethical validity when they act based on a general principle; a principle that makes the person to obey and requires him/ her to accept criteria originated from tradition and to give up to what it stems from the formative conditions and statuses and deep-rooted in their file (Strauss, 1995: 29, 35). 
According to what it mentioned above, the believers in classic natural rights such as Leo Strauss take such an attitude toward basic concepts that form community and politics as follows:

Table 1. Impression of classic natural rights from basic formative concepts of politics and human community

\begin{tabular}{llll}
\hline \multicolumn{1}{c}{ Human fate } & Human rationality & \multicolumn{1}{c}{ Human justice } & Human's best political system \\
\hline All natural organisms & Only human can & Human members are not & The absolute governance \\
including human & achieve these & identical; humans may not be & $\begin{array}{l}\text { system of rational person is } \\
\text { possess a natural fate }\end{array}$ \\
that determines & rights and perceive & assumed as equal to each & deemed as the best political \\
them and s/he can & other since they are not & system; namely, the person \\
goodness or evilness of & never invent it. & identical in terms of & who possesses practical \\
& & achievement of human & wisdom and potential to create \\
& & perfection. & virtuous life. ${ }^{2}$ \\
\hline
\end{tabular}

\section{Definition of Modernity and Its Relation with Modern Political Thought}

As a concept that is placed at the focus point of intellectual, social, and political disputes, modernity lacks a fixed, unique, and stable concept and meaning that one can identify that concept by range of application of that meaning ${ }^{3}$ (Delanty \& Mahoney, 2002:2). It is called as a period in common use of term 'modernity' that with renaissance the rational based on enlightening philosophy started by passing from dictatorial government to bourgeoisie democracy (Lash, 2011: 181). Therefore, modernity includes various aspects with which the thinkers and critiques dealt with each of different dimensions from these perspectives: Some of experts call modernity under title of a philosophical paradigm while a group also considers modernity as a sociological approach that they employ it to refer to lifestyle and social status of those ones who have experienced modern era (Nazari, 2012: 510. But third paradigm of modernity concerns with concept of modern political doctrine. The adherents of this approach argue that emerging of renaissance and its aftermath events caused fundamental transformation of political institutions about concept of power, role and position of ruler, laws and basic rights and acquisition of modern definitions and applications of these concepts so that these developments in political paradigm became the source of changes and probably deep biases in political philosophy. Leo Strauss was one of the thinkers who have followed this modernity approach. Based on attitude of Strauss, the most fundamental and dramatic change occurred at early days of new age reached to peak point in political sciences (Strauss; 2012: 77).

\section{Components of Modern Political Paradigm}

Based on third approach, we will find this point through analysis and critique of modernity in concept of modern political thought that it indicates fundamental and of course modern changes in basic political concept. These elements comprise of: 1) Perception of a new concept of power; 2) Rational approach toward activities; 3) Research in subject of scientific knowledge; and 4) Skepticism in previous meditational theories that have been persisted in them by classic thinkers for long centuries.

\subsection{Perception of a New Concept of Power}

In fact, perception of modernity paradigm is deemed as a viral entry in perceiving of new power concept (Nazari, 2012: 43). Accordingly, emphasis on institutional nature of power that presented a new image of it to human was one of the main components of modernity. It can be perceived that perceiving of new concept of power requires addressing the emerging horizon of modernity. As concept of modern political paradigm, modernity tends to

\footnotetext{
2 - This principle may be considered as equivalent to the platonic paradigm of philosopher king and accordingly Strauss also argues that Plato's treatise that has been well-known as 'Republic' does not basically discuss about republic system or republication in its new impression but the subject of his treatise is governmental system in general or- what Strauss has explained for political philosophy in ancient Greece period- as the best ruling method which is irrelevant to republic. See also for more information (Tabatabaei, vol. 1, chapter I, 2014: 11). Also Aristotle was deeply involved in subject of the best government similar to Plato (Kleskov, 2013: 253).

3 - In book of critique of modernity, Allan Norton argues that there are numerous definitions for term 'modernity' including modernity as acquisition of rationality or rationalization process and obtaining subjectivity or subjectivation process; modernity as renaissance spirit, reformation and enlightenment spirit; and modernity as spirit of science and freedom. Some authors such as Giddens, Habermas, Howard, and Held etc. believe that modernity is creative, constructive, forwarding, and transformed subjectivity that has influenced all fields of biologic world and intellectual and cultural and political life for human at modern age since seventeenth century and by its hegemony. See also for more information: Nozari, Hossein Ali (1999), Modernity and modernism, Tehran: Naqsh-E-Jahan Pub, pp 10-15.
} 
present theoretical supports for justification of political power (Nazari, 2012: 20). A form of political power is noticed in this approach that is called governmental power (Bashiriyeh, 2007: 29).

In fact, at modern era, the sciences relating to study in subject of politics have put the power at the centroid of importance more than ever and political sciences were based on this idea that the political power is an efficient variable for creating transformation in the fields of collective life. If political thinkers at Middle Ages already discussed about two types of worldly and spiritual power in which the worldly power was placed lower than spiritual power in terms of position and the spiritual power had unchangeable status in community as the highest form of realizing power, at present political power was proposed independently in modern attitude regardless of this point to consider requisite for intervention by another power as necessary such as Papal power system for confirmation or supporting from it (Nazari, 2012: 92).

\subsection{Thinking Approach toward Rational Insight (Rational Approach)}

Rationality is the important element of modernity that replaced empirical- deductive paradigm of socialism with scholastic doctrines in order to change thinking method. Here rationality means critical rationality that does not accept anything by faith and it is skeptic about tradition and revelation (Nazari, 2012: 46). Tending to human's rationality, modern doctrine started inquiry in bases of governmental rationality by modern technique similar to the only organizing agent in the field of social life and denial of paradigm of linking among human rationality with metaphysical wisdom. As a result, this issue was proposed that the government is a system that has been created by human's rationality to organize important aspect of social life (Pooladi, 2001: introduction). Likewise, the instrumental rationality mainly governed at modern age that might reduce anything at the level of cost- profit level (Nazari, 2012: 203). In fact, this trend of modern rationalization that was accompanied with a type of opposition and conflicting culture focused all its efforts to defend from individual freedom and emotional experience (Nozari, 1999: 37).

\subsection{Research in Subject of Scientific Knowledge}

Employing theoretical and scientific aspects in exposure to real world and analysis on social activities were one of the features of modernity as concept of the given modern political thought. The post-renaissance centuries include centuries of Descartes, Newton, and Galileo and consider modern scientific insight to mathematical form of language world and nature and the nature and world are assumed as the simplest imaginable mathematical paradigms (Ahmadi, 2001: 63). In other words, the epistemology was established on pragmatism and deductive reasoning in modern paradigm (Bashiriyeh, 2007: 78).

The scientific epistemology tends to perceive, explain, and interpret the facts based on which we can achieve world and phenomena. Similarly, one can deal with nature and limits of knowledge, progress, and their bases by the aid of them and measure reliability in perceptual claims. Based on this concept, scientific theories form our epistemological subjectivity under title of some frameworks for knowledge and make us committed to look at the world from specific perspective and focus on particular aspects of reality (Nazari, 2011:63). Therefore, through creating fundamental turning point in methodological bases of knowledge the modern epistemology tried to create the needed backgrounds for self-knowledge and self-conception in human by proposing a new logic (Habermas, 1981: 7).

\section{4) Skepticism in previous meditational theories}

The modern political though started moving by skepticism in total previous knowledge and findings. The pioneers of modern paradigm lived in the climate where the former meditational theories were subject to skepticism and there was skeptic climate governing over intellectual field (Maggie, 1993: 127). Epistemology was one of the issues that were subject to skepticism. For instance, the persons who believe in possibility for knowledge think that one could express reality independent from knowledge (recognition) within truthful descriptions. One can refer to rationalists and pragmatists in this group. In contrast, one can imply relativists who denied achieving real knowledge and thus essentially disproved epistemology (Moshirzadeh, 2007: 10-11). Despite of these differences, any type of spiritual power may be invalidated beyond field of human's rationality based on attitude of two groups so that to be totally criticized. Of course, denial of metaphysical power may advance in modern paradigm to the extent that according to attitude of some of these thinkers there is no phenomenon under title of God at all (Ahmadi, 2004: 9).

The other point is that The diversity of modern political paradigm versus classic political doctrine- regarding metaphysical theories- starts from this point that the political community is not assumed as a part of a greater cosmos (universal) system but it is a system made of human and dependent on human's will and rationality and the rationality of will which are not function of superior and greater rationality and will. Passing through such a 
point the effort was made in political paradigm duringits dramatic development period from Machiavelli to Nietzsche to interpret and establish quality of intervention by human will and rationality to lay foundation and administer political community (Pooladi, 2001: 9).

Table 2. Impact of modern political paradigm based on fundamentals of classic natural rights

\begin{tabular}{llll}
\hline Human fate and nature & \multicolumn{1}{c}{ Human rationality } & Justice & $\begin{array}{c}\text { Human's best political } \\
\text { system }\end{array}$ \\
\hline $\begin{array}{l}\text { Skepticism in natural } \\
\text { fate and act of God }\end{array}$ & $\begin{array}{l}\text { Change in approach } \\
\text { toward perceiving }\end{array}$ & $\begin{array}{l}\text { Breach of justice- and its } \\
\text { relevant rights- as the fixed and }\end{array}$ & $\begin{array}{l}\text { Rystem relating to } \\
\text { governing over }\end{array}$ \\
$\begin{array}{l}\text { numan's destiny and } \\
\text { disproving it }\end{array}$ & of the laws resulting & accepting it as a conventional & acceptance of will with \\
\hline
\end{tabular}

\section{Strauss' Critique to New Hermeneutics of Modern Political Thought Regarding Bases of Traditional Natural Rights}

The effects that have been exerted by modern political paradigm on bases of classic natural rights made the some thinkers including Strauss to react and criticize to the given paradigms. This reaction may be classified as follows:

1) Change in concept of justice: The modern thinkers claim the history has shown that the justice has achieved different meanings over the time and various cultures have taken different impressions from that concept. Accordingly, at the same time it should be admitted that any right is a conventional and institutional phenomenon so that the legislators interpret them in various countries. But based on Straus' view, it is the problem that pondering in social sciences as a historic phenomenon will lead to making them relativistic and finally the modern knowledge as whole (Strauss, 2012: 26). The fact that we admit any right is an institutional subject is similar that we say the right is only what the legislators and courts determined in various countries while we all know that sometimes it can be implied properly or even certainly that some of laws or decision-making is not fair (Strauss, 1994: 18). Therefore, in such cases, there is no longer any proper or improper fair and or unfair criterion available to use by virtue of them we could judge about conventional rights (Strauss, 1994: 18) and just at this point the risk of relativism may threaten social sciences in general and political philosophy in particular.

2) As it already mentioned, skepticism in natural destiny and act of God governing over human's fate is one of bases that were invaded by modern thinkers i.e. natural fate of human so that the classic philosophers were committed to it over centuries. Skepticism and disproving this part of classic natural rights led to disbelief in human's high values and objectives (Tarcov \& Pangle, 1994: 62) e.g. piety and virtue. Similarly, Strauss extremely opposes to leaving value-driven judgments and according his opinion it is impossible to study all of social phenomena regardless of value-driven judgment (Strauss, 1959: 20). The person, who does not deem it necessary to disgrace individuals whose range of vision is only restricted to food consumption and digestion, may be tolerant subject in terms of econometrics but s/he may not express suitable words about feature of human community. The persons who rejects from distinguishing a great statesman from a moderate person and a mad fraudulent one may be a good bibliographer while s/he cannot imply appropriate statement about politics and political history (Strauss, 2012: 18). Overall, it is almost impossible to perceive a paradigm, function or action without evaluation. Leaving value-driven judgments is based on this assumption that conflict among various values or value-driven systems with each other may not basically resolved by human rationality. But it seen instead is general considerations that seemingly prove this or that value-driven conflict may be irresolvable. It is rational to accept this point that some of value-driven conflicts may not be resolved by human rationality (Strauss, 2012: 21). Belief in that value-driven judgment may not surrender to rational laws in final analysis may encourage us to express irresponsible statements- about true or false and good and evil- more than ever (Strauss, 1959: 23). What Nietzsche suffered in prescription of nihilism indicates this fact. In other words, unlike Plato, Nietzsche does not propose any solution in addition to his extreme tendency to disprove the previous heritagewhat it has so far reached to him (Strauss, 1972: 21).

3) Change approach from perception of natural laws to building of laws based on human's rationality: 
Concerning change in perceiving law to build them is a great bias whether in eighteenth and nineteenth centuries and or at current century where the human concluded that $\mathrm{s} /$ he could establish and interpret all of the needed laws only by equipping with science and rationality power as weapon in this scene. We have not witnessed anything else except French Jacobinism, German Fascism, and Russian Communism (Strauss, 1962-A: 95). All right, the great risk that has been implied by Strauss in above is risk of totalitarianism in its various forms.

With respect to way of Strauss' perception of modern political thought and its elements as well as the critiques he expresses about influence of modern political thought on classic natural rights and the resulting consequences, one can witness Strauss' perception of modern political thought, his critique to modern political paradigm, and the consequences of his attitude toward modern political paradigm with change exerted in bases of natural rights as follows:

Table 3. Leo Strauss' attitude toward perception, critique, and consequences resulting from modern political thought

\begin{tabular}{llll}
\hline \multicolumn{1}{c}{ Basis of natural rights } & \multicolumn{1}{c}{ Human rationality } & $\begin{array}{l}\text { Human's fate and } \\
\text { nature }\end{array}$ & \multicolumn{1}{c}{ Justice } \\
\hline $\begin{array}{l}\text { Strauss' perception of } \\
\text { modern political paradigm }\end{array}$ & $\begin{array}{l}\text { Change in approach } \\
\text { toward perception of } \\
\text { natural rights in building } \\
\text { of laws resulting from } \\
\text { human's rationality }\end{array}$ & $\begin{array}{l}\text { Skepticism in } \\
\text { natural destiny and } \\
\text { act of God } \\
\text { governing over } \\
\text { human's fate and } \\
\text { disproving it }\end{array}$ & $\begin{array}{l}\text { Breach of justice and its } \\
\text { relevant rights as a fixed and } \\
\text { predetermined phenomenon } \\
\text { and accepting it as a } \\
\text { conventional and institutional } \\
\text { activity }\end{array}$ \\
\hline $\begin{array}{l}\text { Strauss' critique to the } \\
\text { exerted changes in natural } \\
\text { rights by modern political } \\
\text { paradigm }\end{array}$ & $\begin{array}{l}\text { Emerging of unfair laws } \\
\text { and institutions resulting } \\
\text { from human's rationality }\end{array}$ & $\begin{array}{l}\text { Disbelief in human's } \\
\text { high values e.g. } \\
\text { piety and virtue }\end{array}$ & $\begin{array}{l}\text { Leaving fixed criteria to } \\
\text { distinguish good from evil } \\
\text { and true from false }\end{array}$ \\
\hline $\begin{array}{l}\text { Consequences of change in } \\
\text { bases of natural rights } \\
\text { influenced by modern } \\
\text { political paradigm } \\
\text { according to Strauss' } \\
\text { attitude }\end{array}$ & Totalitarianism & Nihilism & Relativism \\
\hline
\end{tabular}

\section{Conclusion}

It was tried in this study to analyze Leo Strauss' critiques to modern political paradigm. Hence, this question was raised: What are the distinct features of modern political thought based on Strauss' attitude and what critiques may be proposed to this doctrine? It can be implied that the foremost features of modern political thought are as follows: 1- Perception of new concept of power; 2- Turning paradigm toward rational insight; 3- Research about scientific knowledge (concept); and 4- Skepticism in previous meditational theories and disproving them. The most basic critique that is mentioned by Strauss versus modern political thought is that this paradigm may undermine and or at least weaken classic natural rights and for which it has caused modernity crisis. Accordingly, he concludes that formation of totalitarianism is the consequence of modernity crisis on human's rationality and its impact on disproving natural fate and nature of human with emerging nihilism and finally consequences of this crisis on disproving justice designated by classic natural rights is appearance of relativism. According to Strauss' attitude, what is considered as very important and essential about the requirements, emotions, and tasks for the first modern philosophers is a real activity- not in such a way that stems from teleological nature of course. Although these requirements are naturally visible in city, they are not unchangeable based on ethical and political paradigms. 
The defects that can be attributed to Strauss' critique of modern political thought are that the modernity did not form to the extent that he thought despite of deficient content. Even Machiavelli and Hobs had some concepts of goodness in mind- although with specific interpretation. What it caused Strauss' overlooking in his attitude toward modern political thought relatively returns to this issue that the philosopher does not enter into this cave ${ }^{4}$ neither once nor gradually in total form. Even though philosopher does it whereas s/he is placed within history as well s/he may acquire some facts that remain typically as relative and time-bounded and at certain place and for which the philosopher should constantly and permanently try for this purpose. Therefore, the basic defect of Strauss is in that his perception of first climate of modernity includes perception under specific conditions. His attitude makes it possible to look at modernity only from revolutionary perspective.

\section{References}

Ahmadi, B. (2001). Book of skepticism. Tehran: Markaz Pub.

Ahmadi, B. (2001). Structure and hermeneutics. Tehran: Gam-E-No Pub.

Ahmadi, B. (2004). Modernity and critical thinking (5th ed.). Tehran: Markaz Pub.

Bashiriyeh, H. (2007). History of political paradigms in twentieth century: Liberalism and conservatism (Vol. 2, 7th ed.). Tehran: Nay pub.

Delanty, G., \& O'Mahony, P. (2002). Nationalism and Social Theory: Modernity and the Recalcitance of Nation. London: Sage Publications Ltd.

Freidan, M. (2005). Bases of human rights (transl. Majlesi Fereidoon, 2nd ed.). Tehran: Ministry of Foreign Affairs Printing \& Publication Center.

Ghorbannia, N. (2004, Summer). Various paradigms of natural rights. Quarterly of Islamic Jurisprudence and Law, 1, 37-58.

Kleskov, G. (2010). Political; history (classic era), transl. Deihimi Khashayar, $1^{\text {st }}$ vol., Tehran: Ney Pub.

Kleskov, G. (2013). History of political philosophy (middle ages), transl. Deihimi Khashayar, $2^{\text {nd }}$ vol., Tehran: Ney Pub.

Lash Scott. (2011). Sociology of postmodernism, transl. Behyan Shapoor, $3^{\text {rd }}$ Ed, Tehran: Ghoghnoos Pub.

Maggie, B. (1993). Great philosophers, Fooladvand Ezzatollah. Tehran: Khwarizmi Pub.

Mojtahedi, K. (2011). Philosophy in middle ages (5th ed.). Tehran: Amir Kabir Pub.

Moshirzadeh, H. (2007). Development in theories of international relations. Tehran: SAMT Pub.

Movahed, M. A. (2005). Tendency to right and justice: From natural rights to human rights (3rd ed.). Tehran: Karnameh Pub.

Namazi, R. (2013). Opening the returning path toward the classic scholars from way of criticism of modernity founders. Journal of Mehrnameh, 33.

Nazari, A. A. (2012). Subject, power and politics: From Machiavelli to Foucault. Tehran: Ashian Pub.

Nozari, H. A. (1999). Modernity and modernism. Tehran: Naqsh-E-Jahan Pub.

Pooladi, K. (2001). From sovereign state to rational state in modern political philosophy (2nd ed.). Tehran: Markaz Pub.

Rezvani. (2006). Leo Strauss and Islamic political philosophy. Qom: Imam Khomeini educational and research institute publication center.

Strauss, L. (1994). Natural rights and history, transl. Parham Bagher, $2^{\text {nd }}$ Ed, Tehran: Agah Pub.

Strauss, L. (1959). What is Political Philosophy? And Other Studies. The university of Chicago press.

Strauss, L. (1962). The Three Waves of Modernity. Political Philosophy: Six Essays, ed. Hilial Gildin, Pegasus Bobbs-Merrill.

Strauss, L. (1971). Nietzsche's Beyond Good and Evil. St. John's College, St. John's College, Annapolis, Maryland.

Strauss, L. (1995). Philosophy and Law: Contributions to the Understanding of Maimonides and His

\footnotetext{
${ }^{4}$ - Allegory of Cave (Plato) refers to a shelter-like cave that has been placed in mount but here the author means that the thinker should not generally act without caution and reject or confirm a subject absolutely with perfect confidence.
} 
Predecessors (Suny Series in the Jewish Writings of Strauss). University Of Chicago Press.

Strauss, L. (2012). What is political philosophy? Transl. Rajayee Farhang, vol. 4, Tehran: Scientific \& cultural Publication Company.

Tabatabaei, J. (2011). Textbook of political paradigm chapters: Analysis and critique of Jean Jacque Rousseau's doctrine. Tehran: Political economical (question) studies institute.

Tabatabaei, J. (2014). History of modern political paradigm in Europe: Classic and modern polemic in theologies and politics (Vol. 1, Chapter I). Tehran: Minoo-Ye-Kherad Pub.

Tarcov, N., \& Pangle, T. (1994). Leo Strauss and history of critique to modern government theory in criticism to modern government theory, Edited by Leo Strauss, Transl. Tadayon Ahmad, $1^{\text {st }}$ Ed, Tehran: Kavir Pub.

Habermas, J. (1981). Modernitty Versus Postmodernity. Translated by Seyla Ben-Habib. New German Critique, 22. PP 3.

Parsapoor, M. B. (2010, Winter). Theory of natural rights. Quarterly of philosophical-discursive, 14, $141-151$.

Robertson, N. G. (1998). The Closing Of The Early Modern Mind: Leo Strauss And Early Modern Political Thought. Received June 7, 2015, from http://swgc.mun.ca/animus

\section{Copyrights}

Copyright for this article is retained by the author(s), with first publication rights granted to the journal.

This is an open-access article distributed under the terms and conditions of the Creative Commons Attribution license (http://creativecommons.org/licenses/by/4.0/). 